Vol. 1 No. 2 September 2021, p-2797-5592 | e-2797-5606

\title{
PEMANFAATAN VIDEO PEMBELAJARAN PADA PELATIHAN JARAK JAUH FUNGSIONAL PENYULUH PAJAK (STUDI KASUS BDK DENPASAR)
}

\author{
NAILUL HISAN \\ Widyaiswara Ahli Madya Badan Pendidkan dan Pelatihan Keuangan \\ e-mail: nailul.hisan@kemenkeu.go.id
}

\begin{abstract}
ABSTRAK
Untuk melengkapi bahan Pelatihan Jarak Jauh Fungsional Penyuluh Pajak penyelenggara telah menyiapkan bahan pelatihan diantaranya berupa video pembelajaran. Agar video pembelajaran yang disediakan sesuai kebutuhan peserta maka perlu diketahui persepsi peserta atas video pembelajaran. Penelitian ini menggunakan metode deskriptif yaitu mengetahui nilai variabel yang bersifat mandiri, baik satu variabel atau lebih (independen) tanpa melakukan perbandingan. Data dikumpulkan menggunakan kuesioner dan dokumentasi. Data yang diperoleh berupa data kuantitatif dan data kualitatif. Teknik analisis yang dilakukan untuk data kuantitatif dengan menyajikan data dalam bentuk tabel atau distribusi frekuensi dan tabulasi silang (crosstab). Untuk data kualitatif, penulis melakukan reduksi data dengan menggabungkan jawaban-jawaban yang serupa dalam satu kalimat. Hasil penelitian diketahui bahwa jenis video yang paling diskuai oleh pserta pelatihan adalah jenis video tutorial, sedang durasi video yang disukai peserta adalah video dengan durasi 3-5 menit. Alasan peserta lebih menyukai video pembelajaran dibandingkan dengan media yang lain karena video memenuhi unsur visual, audio, dan sesuai perkembangan zaman Media pembelajaran video dapat memudahkan pemelajar untuk lebih memahami materi. Kelebihan video pembelajaran adalah video pembelajaran lebih mudah diterima dan lebih menarik. Sedangkan kekurangan video pembelajaran adalah komunikasi dalam bentuk video merupakan komunikasi satu arah saja.

Kata kunci: video, pembelajaran, peserta.
\end{abstract}

\section{ABSTRACT}

To complete the distance training of tax advisor functional, the training assistants have prepared the materials, include learning videos. In order to have same expectation as what the participants need, the videos need to know the participants perception of those. This study uses a descriptive method, measuring the value of independent variables without making comparison among others. Data is collected by questionnaires and documentation. It is processed to be quantitative data and qualitative data. The analysis technique for quantitative data is by presenting data in tabular form or frequency distribution and cross tabulation (crosstab). On the other side, for qualitative data, the author reduces the data by combining similar answers in one sentence. The result of these techniques is the most liked-type videos is the tutorial video and the preferred duration ones is within 3-5 minutes. It is because the video have combination of visual, audio, and sophisticating for the participant. The video can help the learners to understand the material better and make the learning more interesting. On the other hand, the lack of the video is only one-way communication.

Key words: video, learning, panticipants.

\section{PENDAHULUAN}

Lembaga Administrasi Negara (LAN) RI sebagai Lembaga yang diberi kewenangan untuk melakukan pengkajian dan pendidikan dan pelatihan ASN (UU Nomor 5 Tahun 2014), telah menerbitkan edaran terkait pelaksanaan pelatihan di masa pandemic covid-19. Dalam Surat Edaran Kepala LAN RI Nomor: 11/K.1/Hkm.02.3/2020 tentang Kewaspadaan dan Pencegahan Penularan Corona Virus Disease (Covid-19) Dalam Penyelenggaraan Pelatihan Teknis, Fungsional dan Sosial Kultural, disebutkan bahwa selama masa pandemi Covid-19, strategi penyelenggaraan pelatihan yang dapat dilakukan adalah: 
1) tetap menjalankan pelatihan sesuai jadwal dan melaksanakan strategi pembelajaran secara normal dengan mempertimbangkan keadaan di lokus masing-masing, disertai dengan penerapan Protokol Kewaspadaan Pencegahan Covid-19 secara disiplin dan ketat;

2) melakukan penjadwalan ulang sampai masa pandemi Covid-19 berakhir; dan/atau

3) melakukan perubahan strategi pembelajaran klasikal menjadi pembelajaran jarak jauh (distance learning);

Menindaklanjuti surat edaran yang diterbitkan oleh LAN RI, maka penyelenggara pelatihan di Kementerian Keuangan (Badan Pendidikan dan Pelatihan Keuangan beserta Pusdiklat dan Balai Diklat Keuangan di daerah) telah menyelenggarakan pelatihan secara jarak jauh jauh (distance learning). Salah satu pelatihan yang diselenggarakan secara jarak jauh adalah Pelatihan Jarak Jauh (PJJ) Fungsional Penyuluh Pajak dengan pemilik program Pusdiklat Pajak.

PJJ Fungsional Penyuluh Pajak dilaksanakan dalam rangka mempersiapkan pegawai pada Direktorat Jenderal Pajak (DJP) menjadi pejabat fungsional penyuluh pajak. Pegawai DJP yang telah memenuhi yang telah memenuhi syarat sebagai pejabat fungsional penyuluh pajak perlu diberi pelatihan khusus terkait dengan teknik-teknik penyuluhan. Hal ini sesuai dengan tujuan PJJ Fungsional Penyuluh Pajak adalah meningkatkan pengetahuan dan keterampilan calon pejabat Fungsional Penyuluh Pajak Direktorat Jenderal Pajak dalam melakukan penyuluhan.

Penyelenggara kegiatan ini adalah Pusdiklat Pajak dan sepuluh Balai Diklat Keuangan di berbagai provinsi. Untuk mendukung pembelajaran tersebut tim pengajar telah menyiapkan materi yang berupa bahan ajar, bahan paparan dan video pembelajaran. Materi tersebut dituangkan ke dalam Learning Management System (LMS) dan diunggah di google site. Setelah seluruh mata pelatihan disampaikan kepada peserta selama lima hari kerja, panitia penyelenggaran menyampaikan kuesioner yang diantara pertanyaannya adalah dalam pembelajaran yang dilakukan secara mandiri bentuk materi seperti apa yang paling disukai? Pilihan jawaban adalah a. bahan ajar, b. bahan paparan/slide, dan c. video pembelajaran.

Hasil kuesioner awal yang disampaikan oleh peserta PJJ Fungsional Penyuuh Pajak dari seluruh unit kerja yang menyelenggarakan pelatihan adalah sebagaimana dalam tabel 1.

Tabel 1. Jenis Media Pembelajaran yang disukai

\begin{tabular}{|l|l|l|}
\hline No. & Jenis Media Pembelajaran & Persentase \\
\hline 1. & bahan paparan (slide) & $24,39 \%$ \\
\hline 2. & video pembelajaran & $59,76 \%$ \\
\hline 3. & bahan ajar & $15,85 \%$ \\
\hline & Jumlah & $100 \%$ \\
\hline
\end{tabular}

Berkenaan dengan data di atas, maka penulis tertarik untuk meneliti mengenai persepsi peserta pelatihan dalam pemanfaatan video pembelajaran pada Pelatihan Jarak Jauh Fungsional Penyuluh Pajak. Dalam penelitian membatasi lokasi pelaksanaan pelatihan yang diselenggarakan oleh BDK Denpasar, sesuai dengan kelas yang penulis ampu. Dengan diketahuinya persepsi peserta pelatihan terhadap video pembelajaran yang diunggah di LMS, maka hal ini akan menjadi masukan penulis untuk dapat mempersiapkan materi dalam bentuk video pembelajaran yang lebih menarik perhatian bagi peserta. Dengan video pembelajaran yang lebih menarik sesuai dengan harapan peserta, maka video tersebut dapat bermanfaat untuk mendukung kegiatan pelatihan yang diselenggarakan oleh BPPK.

Salah cara untuk mencapai tujuan pembelajaran adalah adanya peran pengajar dalam menyampaikan materi dan media pembelajaran sebagai alat bantu untuk mendukung keberhasilan proses pembelajaran. Untuk memahami media pembelajran perlu dilihat dari dua aspek yaitu pengertian dari sudut bahasa dan pengertian berdasarkan terminology. Sesuai dengan kamus besar Bahasa Indonesia asal katan media adalah alat, sarana, perantara dan bahan 
untuk memasukkan penyimpanan data di computer. Dalam hal ini penulis mengambil arti media pembelajaran dari sudut Bahasa adalah alat atau sarana untuk mendukung pembelajaran.

Miarso (2004:392) menyampaikan bahwa yang dimaksud dengan media pembelajaran adalah segala sesuatu yang digunakan sebagai alat untuk menyampaikan pesan serta dapat merangsang pikiran, perhatian, perasaan dan kemauan peserta pembelajaran sehingga dapat mendorong terjadinya proses belajar yang disengaja, memiliki tujuan dan dapat dikendalikan. Media pembelajaran, menurut Sumiharsono (2017: 14) merupakan bagian yang tidak terpisahkan dari keseluruhan kegiatan pembelajaran. Hal ini mengandung pengertian bahwa media pembelajaran sebagai salah salah satu komponen yang tidak dapat berdiri sendiri namun saling terkait dengan komponen pembelajaran lainnya untuk menciptakan kondisi pembelajaran yang diharapkan.

Agar lebih efektif untuk membantu proses pembelajaran pengajar perlu melakukan analisis terkait media pembelajaran yang akan digunakan. Pemilihan media pembelajaran perlu memperhatikan kriteria-kriteria yang disesuaikan dengan tujuan pembelajaran atau kompetensi yang harus dikuasi oleh peserta pembelajaran. Arsyad (2017:74) menyampaikan bahwa kriteria pemilihan media pembelajaran merupakan sumber dari konsep tentang media pembelajaran adalah bagian dari sistem instruksional secara keseluruhan.

Berikut ini beberapa kriteria yang perlu diperhatikan dalam memilih media pembelajaran yaitu sesuai dengan tujuan pembelajaran yang ingin dicapai, serta tepat dalam mendukung konten pelajaran yang bersifat fakta, konsep, dapat berlaku umum, praktis, fleksibel dan bertahan lama. Disamping itu pengajar harus mampu menggunakan media pembelajaran tersebut.

Dalam memanfaatkan media pembelajaran tidak diperkenankan hanya sekedar untuk memancing perhatian siswa atau hanya untuk permainan belaka. Media pembelajaran yang digunakan diharapkan dapat berfungsi untuk mempercepat proses belajar. Dengan demikian peserta pelatihan dapat dengan cepat dan mudah menangkap tujuan dari bahan ajar yang diberikan. Pembelajaran jarak jauh yaitu pembelajaran yang menerapkan sistem aktivitas pembelajaran yang tidak berlangsung dalam suatu ruangan kelas, sehingga tidak ada interaksi langsung secara tatap muka antara pengajar dan pembelajarnya (Munir, 2009).

Dengan perkembangan teknologi informasi dan komunikasi, interaksi antara pengajar dan pembelajar dapat dilakukan, baik dalam bentuk real time (waktu nyata) atau areal time (waktu tidak nyata). Interaksi ini sangat mungkin untuk dilakukan dengan menggunakan berbagai macam media pembelajaran supaya mudah dijangkau pembelajar dalam mendapatkan materi pembelajaran atau informasi-informasi lainnya, seperti media komputer dengan internetnya. Interaksi dalam bentuk real time (synchronous) yang dapat dilakukan antara lain melakukan interaksi langsung atau pertemuan secara online (online meeting), real audio atau real video, facebook dan chatroom. Sedangkan interaksi yang areal time (asynchronous) bisa dilakukan dengan mailing list, discussion group, newsgroup, dan bulletin board. Dengan real time menjadikan adanya interaksi antara pengajar dan pembelajar dapat menggantikan interaksi langsung secara tatap muka, meskipun tidak sepenuhnya.

Dalam kegiatan pembelajaran yang dilaksanakan secara jarak jauh, peserta didik tidak diharuskan atau diwajibkan untuk datang ke sekolah maupun kampus atau tempat pelatihan untuk melaksanakan pembelajaran. Dalam suasana pandemi COVID-19 ini, pelatihan jarak jauh telah sejalan dengan kebijakan pemerintah yaitu membatasi aktivitas manusia di luar rumah. Upaya ini bertujuan untuk membatasi interaksi antar banyak orang untuk memutus mata rantai penyebaran COVID-19. Dengan adanya kebijakan tersebut maka Lembaga pelatihan menerapakan kegiatan belajar mengajar dari jarak jauh atau pembelajaran daring (dalam jaringan).

Banyak sarana yang pada akhirnya diterapkan oleh tenaga pendidik untuk melaksanakan kegiatan belajar mengajar secara jarak jauh. Sarana pembelajaran jarak jauh tersebut tidak dapat dihindari dari perkembangan teknologi informasi dan komunikasi. Sarana pembelajaran tersebut di antaranya aplikasi google meet, aplikasi zoom, google classroom, you tube, video 
pembelajan maupun media sosial whatsapp, telegram dan lain-lain. Semua sarana yang digunakan untuk mendukung pelatihan jarak jauh dihasilkan dari perkembangan teknologi informasi dan komunikasi yang semakin maju.

Menurut Undang-Undang Nomor 20 Tahun 2003 tentang Sistim Pendidikan Nasional (SISDIKNAS), yang dimaksud dengan pendidikan jarak jauh (PJJ) adalah pendidikan yang peserta didiknya terpisah dari pendidik dan pembelajarannya menggunakan berbagai sumber belajar melalui teknologi komunikasi, informasi dan media lainnya. Menurut Keputusan Kepala Badan Pendidikan dan Pelatihan Keuangan Nomor 82/PP/2020 disebutkan bahwa Pelatihan Jarak Jauh (Distance Leaming) yang kemudian disingkat PJJ merupakan proses pembelajaran yang dilaksanakan di luar tempat penyelenggaraan pelatihan yang menekankan pada pembelajaran mandiri yang dikelola secara sistematik dan tidak terbatas oleh jarak dan waktu dengan menggunakan berbagai media pembelajaran.

Dalam pelaksanaan pelatihan/pembelajaran jarak jauh pengajar dituntut dapat memberikan motivasi kepada peserta pelatihan dan mampu menyampaikan materi lebih menarik. Metode dan media pembelajaran tertentu yang digunakan dapat berperan dalam mendukung keberhasilan pembelajaran. Untuk itu pengajar harus mampu lebih kreatif dalam memilih metode dan media pembelajaran yang tepat.

Dalam rangka beradaptasi dengan perkembangan teknologi informasi, kegiatan pelatihan harus mampu memanfaatkan kemajuan teknologi informasi. Media-media pembelajaran yang telah dikembangkan saat ini dapat dijadikan sebagai alternatif untuk mendukung kelancaran proses belajar mengajar. Salah satu Media pembelajaran yang memanfaatkan teknologi adalah video pembelajaran. Penggunaan video pembelajarn dapat memenuhi kebutuhan peserta pelatihan karena video merupakan salah satu media pembelajaran yang menggunakan keuatan suara dan gambar (Pamungkas dkk, 2018).

Alasan penggunaan media pembelajaran dengan video adalah pertama, untuk melengkapi dan media tambahan pada materi-materi yang tidak tercantum dalam modul atau bahan ajar. Kedua, dalam proses pembelajaran terdapat kegiatan mengamati yang terdiri dari membaca, mendengar dan melihat, sehingga video ini sangat bagus untuk memenuhi kebutuhan tersebut. Ketiga, dapat meningkatkan konsentrasi belajar bagi peserta pelatihan, karena video pembelajaran sifiatnya lebih visual. Hal ini seuai dengan fungsi media pembelajaran yaitu fungsi kognitif yang mengungkapkan bahwa media pembelajran yang visual akan memperlancar pencapaian tujuan untuk memahami dan mengingat informasi (Agustiningsih, 2015).

Salah satu pelatihan yang memanfaatkan video untuk mendukung media pembelajaran adalah Pelatihan Jarak Jauh Fungsional Penyuluh Pajak. Pelatihan ini diprogramkan dan dirancang oleh Pusdiklat Pajak salah satu unit kerja yang ada di Badan Pendidikan dan Pelatihan Keuangan. Pusdiklat Pajak memiliki tanggung jawab untuk memfasilitasi kebutuhan pelatihan bagi pegawai Direktorat Jenderal Pajak.

Pelatihan Jarak Jauh (PJJ) Fungsional Penyuluh Pajak diselenggrakan oleh Pusdiklat Pajak dan Balai Diklat Keuangan. Pelatihan ini dilaksanakan dengan tujuan untuk mendukung pelaksanaan reformasi birokrasi di bidang perpajakan serta untuk mencetak tenaga fungsional penyuluh pajak dan fungsional asisten penyuluh pajak yang professional. Jabatan Fungsional Penyuluh Pajak dan Jabatan Fungsional Asisten Penyuluh Pajak terbentuk sesuai dengan Peraturan Menteri Pendayagunaan Aparatur Negara dan Reformasi Birokrasi (PANRB) Nomor 49 Tahun 2020 tentang jabatan fungsional penyuluh pajak serta Permenpan RB Nomor 50 Tahun 2020 tentang jabatan fungsional asisten penyuluh pajak.

Untuk itu perlu ditetapkan Standar Kompetensi Jabatan yang merupakan uraian persyaratan kompetensi yang harus dimiliki dalam melaksanakan tugasnya. Persyaratan kompetensi tersebut terdiri dari dari dua unsur pembentuk yaitu kompetensi teknis dan non teknis. Kompetensi teknis yaitu peserta diharapkan mampu menguraikan pengetahuan dan keterampilan yang dipersyaratkan untuk pegawai dalam melaksanakan pekerjaan sesuai jabatan. Sedangkan kompetensi non teknis yaitu peserta diharapkan mampu menerapkan 
perilaku dan manajerial) yang menguraikan sikap kerja, perilaku, dan kemampuan manajerial yang dibutuhkan pegawai dalam melaksanakan proses pekerjaan.

Salah satu mata pelajaran yang disampaikan pada pelatihan ini adalah Kemampuan Komunikasi serta Metode dan Teknik Penyuluhan. Penyampaian materi ini dilakukan dengan beberapa cara yaitu ceramah dari pengajar, menyaksikan video pembelajaran, diskusi antar peserta serta praktik komunikasi dan menerapkan teknik-teknik penyuluhan. Dalam diskusi kelompok peserta pelatihan diminta untuk mengamati video pembelajaran, hasil praktik-praktik yang dilakukan kelompok lain dan menyampaikan hasil diskusi.

Untuk mengukur tingkat keberhasilan pelatihan ini, peserta diuji dengan cara melakukan praktik penyuluhan secara perorangan. Dalam praktik penyuluhan peserta diharapkan dapat menerapkan materi-materi pelatihan yang telah diterima. Agar peserta mengetahui kemampuannya dalam memberi penyuluhan, penguji memberikan catatan atas pelaksanaan praktik. Catatan tersebut disampaikan kepada perserta agar dijadikan bahan masukan untuk pelaksanaan penyuluhan yang sesungguhnya.

\section{METODE PENELITIAN}

Jenis penelitian yang digunakan adalah penelitian deskriptif. Menurut Sugiyono (2008), Penelitian desktiptif adalah penelitian yang dilakukan dengan tujuan untuk mengetahui nilai variabel yang bersifat mandiri, baik satu variabel atau lebih (independen) tanpa melakukan perbandingan atau mengkaitkan dengan variabel yang lain. Dalam penelitian deskriptif cenderung tidak diperlukan untuk mencari atau menjelaskan saling keterkaitan antar variable dan menguji hipotesis.

Teknik pengumpulan data yang akan digunakan adalah penyampaian kuesioner dan telaah dokumen. Data yang sudah terkumpul kemudian diolah dan dideskripsikan lebih lanjut atas hasil pengolahan data. Hardani dkk (2010), menyebutkan bahwa terdapat dua jenis data yang dikumpulkan untuk mendukung penelitian yaitu data primer dan data sekunder. Jenis data primer adalah sumber bahan atau dokumen yang dikemukakan atau dikumpulkan sendiri oleh orang atau pihak yang meneliti pada waktu kejadian yang digambarkan tersebut berlangsung, Sedangkan jenis data sekunder adalah sumber data diperoleh dari pihak lain yang tidak ikut pada waktu kejadian.

Teknik analisis yang dilakukan adalah untuk data statistik yang diperoleh penulis dilakukan penyajian data dalam bentuk tabel atau distribusi frekuensi dan tabulasi silang (crosstab). Dengan penyajian ini akan diketahui kecenderungan hasil temuan data yang diperoleh, apakah masuk dalam kategori rendah, sedang atau tinggi. Sedangkan untuk data yang diperoleh dari pertanyaan terbuka berupa data kualitatif, penulis melakukan reduksi data dengan menggabungkan jawaban-jawaban yang serupa dalam satu kalimat. Tahap berikutnya dari analisis data ini adalah membandingkan antara persepsi peserta dengan fakta bahan video yang disediakan oleh penyelengaara pelatihan. Kemudian tahap terakhir analisis data adalah mengambil kesimpulan kejadian-kejadian yang ditemui saat penelitian.

\section{HASIL DAN PEMBAHASAN}

Berdasarkan data yang diperoleh dari kuesioner kepada peserta pelatihan penulis membagi dua kelompok besar yaitu jawaban dari pertanyaan tertutp dan jawaban dari pertanyaan terbuka. Untuk pertanyaan yang sifatnya tertutup berisi pendapat siswa mengenai jenis video yang disukai dan lamanya durasi video yang ideal menurut responden. Jenis video yang disajikan dalam materi pembelajaran adalah video tutorial, video yang berisi contoh perilaku, video penjelasan materi, dan video film pendek. Perbandingan pendapat peserta mengenai jenis video pembelajaran yang disukai dan video yang disediakan oleh penyelenggaran adalah sesuai tabel 2 . 
Tabel 2. Perbandingan pendapat peserta pelatihan dan jenis video yang tersedia

\begin{tabular}{|l|l|r|r|}
\hline No. & Jenis Video & Persepsi Peserta & Video yang tersedia \\
\hline 1. & Tutorial & $45,83 \%$ & $20,00 \%$ \\
\hline 2. & Contoh Perilaku & $16,67 \%$ & $16,00 \%$ \\
\hline 3. & Penjelasan Suatu Materi & $12,50 \%$ & $40,00 \%$ \\
\hline 4. & Film Pendek & $25,00 \%$ & $24,00 \%$ \\
\hline
\end{tabular}

Dari data di atas dapat disampaikan bahwa jenis video yang paling disukai peserta adalah video dalam bentuk tutorial yaitu mencapai $45,83 \%$, namun jenis video tersebut disediakan oleh penyelenggara sebanyak $20 \%$ dari total video yang disediakan. Sedangkan video yang paling tidak disukai peserta adalah video dalam bentuk penjelasan suatu materi yaitu $12,50 \%$. Apabila dibandingkan antara persepsi peserta dengan jenis video yang disediakan adalah video yang paling disukai peserta ternyata bukan merupakan video yang paling banyak disediakan oleh penyelenggara. Sedangkan jenis video yang paling banyak disediakan penyelenggara ternyata paling tidak disukai oleh peserta yaitu jenis video penjelasan suatu materi.

Pada saat penulis mengidentifikasi durasi video yang disediakan oleh penyelenggara, ternyata durasinya berberda-beda. Agar dalam pembuatan video ke depan durasinya sesuai dengan yang diinginkan oleh peserta, maka penulis perlu mengenai mengenai persepsi durasi video menurut peserta. Berikut pada tabel 3 disampaikan perbandingan durasi video yang disukai peserta dengan yang disediakan oleh penyelenggara pelatihan.

Tabel 3. Durasi Video Pembelajaran

\begin{tabular}{|l|l|r|r|}
\hline No. & Durasi Video & Persepsi Peserta & Video yang tersedia \\
\hline 1. & Kurang dari 3 menit & $20,69 \%$ & $28,00 \%$ \\
\hline 5. & $3-5$ menit & $65,52 \%$ & $20,00 \%$ \\
\hline 6. & $5-7$ menit & $10,34 \%$ & $36,00 \%$ \\
\hline 7. & Lebih dari 7 menit & $3,45 \%$ & $16,00 \%$ \\
\hline
\end{tabular}

Sumber: hasil kuesioner yang diolah

Selain itu persepsi peserta pelatihan terhadap durasi video pembelajaran dapat Digambar dalam grafik berikut:

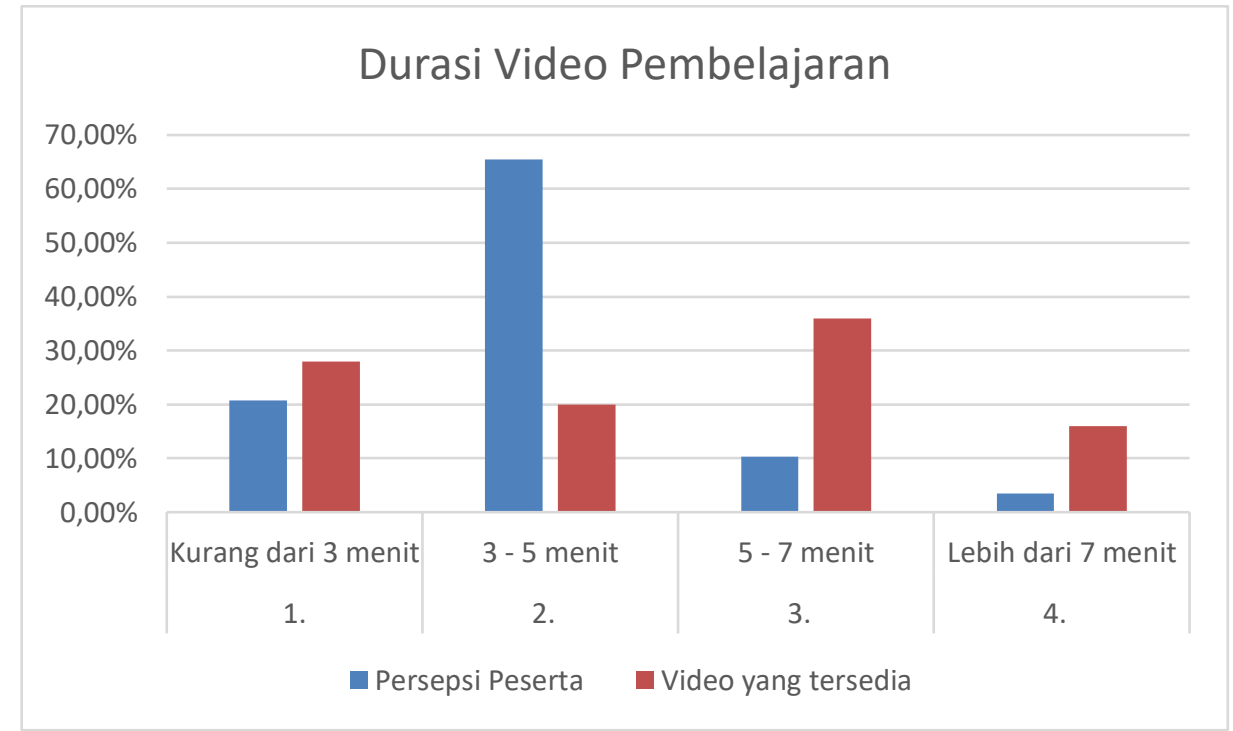

Gambar 1. Grafik Durasi video pembelajaran

Dari data di atas dapat disampaikan bahwa jenis video yang paling disukai peserta adalah video dengan durasi 3-5 menit, sebanyak $65,52 \%$ peserta menyukai video tersebut. Video dengan durasi 3-5 menit telah disediakan oleh panitia sebanyak20\%. Adapun video yang tidak disukai oleh peserta adalah video dengan durasi lebih dari 7 menit. Hanya 3,45\% yang menyukai video tersebut. Hal ini sudah sejalan jumlah video yang disediakan oleh panitia. Video dengan durasi lebih dari 7 menit disediakan paling sedikit dari total video yang tersedia $(16 \%)$. 
Memperhatikan fakta di atas, diharapkan penyelenggara dapat menjadikan bahan masukan apabila menyediakan video pada platform pembelajaran. Dengan demikian bahanbahan pembelajaran yang disediakan dapat lebih bermanfaat bagi peserta pelatihan.

Berikut ini disampaikan pendapat peserta mengenai alasan video pembelajaran lebih disukai daripada media pembelajaran yang lain adalah:

1) Memenuhi unsur visual, audio, dan sesuai perkembangan zaman saat sebagian besar materi diperoleh dari asupan video Youtube, karena ada narasinya disertai gambar, mirip dengan ada pengajar dan power point di ruang kelas,

2) Dapat memberikan penjelasan yang lebih apalagi jika video memuat mengenai contoh pelaksanaan (praktek). Karena video pembelajaran dapat berisikan semua materi yang perlu dipelajari dan yang paling penting adalah video dapat diputar kapan saja ketika ingin belajar,

3) Lebih menarik secara visual dan lebih mudah dipahami untuk tipe auditori dan visual.

4) Memudahkan pembelajar untuk lebih memahami materi, terutama untuk tipe pembelajar auditori-visual, serta untuk mengurangi rasa jenuh dalam menerima materi jika yang disajikan hanya berupa tulisan.

Adapuan kelebihan dan kekurangan video yang digunakan sebagai pelengkap bahan ajar pada pelatihan menurut peserta adalah sebagai berikut:

a. Pendapat peserta terkait kelebihan video pembelajaran digunakan untuk mendukung pelatihan adalah video pembelajaran lebih mudah diterima dan tidak harus menyediakan $100 \%$ fokus pada video, dapat dipelajari sambil menulis/mencatat/mempraktekkan. Peserta juag berbendapat bahwa video pembelajaran lebih menarik karena lebih visual dan menampilkan gambar bergerak sehingga penjelasan bisa lebih detail, dapat diputar dan dipelajari berulang-ulang apabila terdapat materi yang masih belum jelas, Dalam hal manfaat video pembelajaran peserta berpendapat bahwa materi dalam video dapat membantu peserta memahami materi lebih cepat, belajar menjadi lebih menarik dan tidak membosankan serta bisa didengarkan berulang kali. kombinasi materi dalam bentuk audio dan visual, terdapat gambar bergerak untuk mengurangi kejenuhan dalam menerima materi, serta terdapat kombinasi warna yang variative, Tidak cenderung monoton seperti media pembelajaran yang hanya berisi tulisan

b. Pendapat peserta mengenai kekurangan video pembelajaran untuk mendukung suatu pelatihan adalah komunikasi dalam bentuk video merupakan komunikasi satu arah saja, sehingga yang menyaksikan video tidak bisa berinteraksi. Pertanyaan yang disampaikan penonton dilakukan dengan cara meninggalkan pesan di kolom komentar, atau pesan pribadi. Jika ada pertanyaan dari penonton tentunya memerlukan penjelasan lebih lanjut dari pengajar atau orang yang membuat video dan tidak bisa dijawab secara langsung oleh pembuat video, Untuk mengkses video pembelajaran yang masih tersambung di media online memerlukan kuota dan jaringan internet yang bagus, memerlukan peralatan untuk mengaksesnya.

Peserta memberikan saran agar video yang disediakan berisi materi yang disampaikan secara sistematis disertai contoh-contoh kasus yang mudah diimplementasikan. Apabila video tersebut diproduksi sendiri diharapkan memiliki kualitas gambar dan suara yang memadai. Video yang dibuat dinamis dengan memperhatikan pergantian layar, angle video atau animasi agar tidak bosan. Diharapkan dibuat dengan durasi yg tidak terlalu lama agar tidak ada kendala jaringan yang sering buffering, Video yang dibuat agar lebih menarik untuk ditonton dan memudahkan pembelajar untuk mempelajari materi, serta durasi yang tidak terlalu panjang namun sudah mencakup semua materi yang harus disampaikan, Mungkin bisa kedepannya media pembelajaran dalam bentuk video bisa dibuat pembelajaran secara interaktif, lebih bagus menggunakan video yang interakitf. Video harus dibuat semenarik mungkin agar dapat menarik perhatian. Kurangi penggunaan text yang mendominasi, pastikan ukuran file dicompress sedemikian rupa (tanpa mengurangi kualitas) agar bisa diakses lebih ringan dari device manapun.

Berdasarkan pendapat peserta mengenai video pembelajaran dapat diperoleh informasi bahwa video pembelajaran memenuhi unsur visual, audio dan sesuai dengan perkembangan 
jaman. Selain itu video pembelajaran dapat memudahkan peserta pelatihan untuk memahami suatu materi yang disampaikan oleh pengajar. Hal ini sesuai dengan apa yang disampaikan oleh Agustiningsih (2015) yaitu, video pembelajaran dapat dapat meningkatkan konsentrasi belajar bagi peserta pelatihan, karena video pembelajaran sifiatnya lebih visual. Video pembelajaran juga sesuai dengan fungsi media pembelajaran yaitu fungsi kognitif yang mengungkapkan bahwa media pembelajran yang visual akan memperlancar pencapaian tujuan untuk memahami dan mengingat informasi. Jika pendapat peserta pelatihan mengenai video pembelajaran dikaitkan dengan pendapat Pamungkas dan kawan-kawan, hal ini juga sudah sesuai. Penggunaan video pembelajarn dapat memenuhi kebutuhan peserta pelatihan karena video merupakan salah satu media pembelajaran yang menggunakan keuatan suara dan gambar (Pamungkas dkk, 2018).

\section{KESIMPULAN}

Jenis video yang paling diskuai oleh pserta pelatihan adalah jenis video tutorial, sedang durasi video yang disukai peserta adalah video dengan durasi 3-5 menit. Alasan peserta lebih menyukai video sebagai media pembelajaran dibandingkan dengan media yang lain adalah video memenuhi unsur visual, audio, dan sesuai perkembangan zaman Media pembelajaran video dapat memudahkan pemelajar untuk lebih memahami materi. Kelebihan materi dalam bentuk video adalah lebih menarik karena lebih visual dan menampilkan gambar bergerak sehingga penjelasan bisa lebih detail, dapat diputar dan dipelajari berulang-ulang. Kekurangan media pembelajaran video adalah video merupakan komunikasi satu arah saja, sehingga yang menyaksikan video tidak bisa berinteraksi dengan pembuat video atau penyaji. Disamping itu untuk mengakses video dibutuhkan kuota dan jaringan internet yang bagus.

Dalam penelitian memberi saran agar penyelenggara pelatihan yang menyedia materi dalam bentuk video perlu memperhatikan durasi dan jenis video yang disampaikan. Selain itu jika video diproduksi sendiri memperhatikan kualitas gambar dan suaranya agara hasilnya dapat diterima dengan baik.

\section{DAFTAR PUSTAKA}

Afrizal. (2014). Metode Penelitian Kuallitatif. Jakarta. PT. Rajagrafindo Persada

Agustiningsih, Agustiningsih. (2015). Video Sebagai Alternatif Media Pembelajaran Dalam Rangka Mendukung Keberhasilan Penerapan Kurikulum 2013 di Sekolah Dasar. PEDAGOGIA, Volume 4 Nomor 1

Arsyad, A. (2017). Media Pembelajaran. Jakarta. PT Rajagrafindo Persada.

Badan Pendidikan dan Pelatihan Keuangan. (2020). Keputusan Kepala Badan Pendidikan dan Pelatihan Keuangan Nomor 82/PP/2020 tentang Panduan Penyelenggaraan Pelatihan Jarak Jauh (Distance Learning) Di Lingkungan Badan Pendidikan Dan Pelatihan Keuangan

Djamarah Syaiful Bahri dan Sawan Zain. (2014). Strategi Belajar Mengajar. Jakarta. PT Rineka Cipta

Hamdani. (2010). Startegi Belajar Mengajar. Bandung: CV Pustaka Setia.

Hardani, J. U. (2020). Buku Metode Penelitian Kualitatif \& Kuantitatif. Yogyakarta: CV. Pustaka Ilmu

Menteri Pendayagunaan Aparatur Negara dan Reformasi Birokrasi (PANRB). (2020). Peraturan Menteri PANRB Nomor 49 Tahun 2020 tentang Jabatan Fungsional Penyuluh Pajak.

Miarso, Y. (2004). Menyemai Benih Teknologi Pendidikan. Jakarta: Pustekkom Diknas.

Munir. (2009). Pembelajaran Jarak Jauh Berbasis Teknologi Informasi dan Komunikasi. CV. Alfabeta. Bandung

Pamungkas, A. S., Ihsanudin, I., Novaliyosi, N., \& Yandari, I. A. V. (2018). Video Pembelajaran Berbasis Sparkol Videoscribe: Inovasi pada Perkuliahan Sejarah Matematika. Prima: Jurnal Pendidikan Matematika. 
Republik Indonesia. (2003). Undang-Undang Nomor 20 Tahun 2003 tentang Sistim Pendidikan Nasional (SISDIKNAS)

Sugiyono. 2008. Metodologi penelitian Kuantitatif, Kualitatif, dan R\& D. Bandung: Alfabeta. Sumiharsono, R. (2017). Media Pembelaaran. Jember: CV. Pustaka Abadi. 